\title{
WestVirginiaUniversity
}

THE RESEARCH REPOSITORY @ WVU

Graduate Theses, Dissertations, and Problem Reports

1998

\section{Synthesis and reactions of antimony allyloxides}

\author{
Matthew Alan Moser \\ West Virginia University
}

Follow this and additional works at: https://researchrepository.wvu.edu/etd

\section{Recommended Citation}

Moser, Matthew Alan, "Synthesis and reactions of antimony allyloxides" (1998). Graduate Theses,

Dissertations, and Problem Reports. 922.

https://researchrepository.wvu.edu/etd/922

This Thesis is protected by copyright and/or related rights. It has been brought to you by the The Research Repository @WVU with permission from the rights-holder(s). You are free to use this Thesis in any way that is permitted by the copyright and related rights legislation that applies to your use. For other uses you must obtain permission from the rights-holder(s) directly, unless additional rights are indicated by a Creative Commons license in the record and/ or on the work itself. This Thesis has been accepted for inclusion in WVU Graduate Theses, Dissertations, and Problem Reports collection by an authorized administrator of The Research Repository @ WVU. For more information, please contact researchrepository@mail.wvu.edu. 


\title{
Synthesis and Reactions of Antimony Allyloxides
}

\author{
Matthew A. Moser \\ Masters of Science \\ in Inorganic Chemistry \\ Dr. Fred King \\ Dr. Robert Nakon \\ Dr. Katharine Covert, Chair
}

Dec. 3, 1998

West Virginia University

Keywords: antimony, allyloxide, alkoxide 


\section{Acknowledgement}

I would like to start by thanking my Lord, my family and my friends for their support and guidance. Without their help none of this could have been accomplished. I would like to extend my deepest thanks to Dr. Covert, my research advisor, for her guidance and helpfulness during the completion of my research project. I would also like to thank Dr. Nakon and Dean King, my research committee for their help, time and suggestions.

I would like to thank all of the staff in the department as well as my fellow students. I would like to thank all my friends in the department, past and present, that made my stay here enjoyable. I would also like to thank Holly Mason not only for her help but also for making the lab a fun place to work. Finally, I would like to thank Gary for all of his help and his friendship. Thanks for the "Big Nasty " experience. 
Synthesis and Reactions of Antimony Allyloxides

Matthew A. Moser

\section{Abstract}

Heterogeneous catalysts usually consist of a high metal oxide or metal dispersed on a reducible oxide support. "Inert" supports have been shown to be intimately involved in heterogeneous catalytic processes. Of interest is the $\mathrm{MoO}_{3} / \mathrm{Sb}_{2} \mathrm{O}_{3}$ catalyst used in the ammoxidation of propene to acrylonitrile. Simple molybdenum complexes have provided a model for the role of the $\mathrm{MoO}_{3} / \mathrm{Sb}_{2} \mathrm{O}_{3}$ catalyst, but the role of the support is not well understood. In order to better understand the role of the support, a series of antimony allyloxide compounds of the formula $\mathrm{Sb}(\mathrm{OR})_{3}($ where $\mathrm{OR}=$ allyl oxide, 3-Methyl-2-buten-1-oxide, 2-Methyl-3-buten-2-oxide, and 3-Methyl-3buten-1-oxide) by metathesis and alcoholysis methods ( $70 \%$ yield) were synthesized. Compounds of the formula $\mathrm{SbMe}(\mathrm{OR})_{2}$ and $\mathrm{SbMe}_{2}(\mathrm{OR})$ ( where OR = allyl oxide, 3-Methyl-2-buten-1-oxide, 2-Methyl-3-buten-2-oxide, and 3Methyl-3-buten-1-oxide) were synthesized only by a metathesis reaction between $\mathrm{SbMeI}_{2}$ and $\mathrm{SbMe}_{2} \mathrm{I}$ and the sodium salt of the desired alcohol ( 35$60 \%$ yields). Compounds of the formula $\mathrm{SbMe}_{3}(\mathrm{OR})_{2}$ ( where OR $=3$-Methyl3-buten-2-oxide and 2,6-diisopropyl phenoxide compounds) were synthesized by a metathesis reaction between $\mathrm{SbMe}_{3} \mathrm{I}_{2}$ and the sodium salt of the desired alcohol ( $~ 54 \%$ yield). Reactions of $\mathrm{Sb}(\mathrm{OR})_{3}$ and $\mathrm{SbMe}(\mathrm{OR})_{2}$ with multiple oxidizing agents were attempted in order to obtain the corresponding $\mathrm{Sb}(\mathrm{V})$ oxo compounds. The synthesis and reactions with oxidizing agents are discussed along with the relevance of this research to the heterogeneous oxidation process. 


\section{Table of Contents}

Title page............................................................

Acknowledgement....................................................ii

Abstract ...........................................................ii

Table of Contents ..................................................... iv

List of Tables........................................................

List of Schemes ....................................................... vi

List of Figures....................................................... vii

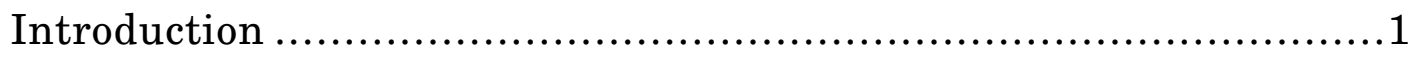

Experimental........................................................ 11

Results and Discussion ..............................................25

References............................................................42

Approval of Examining Committee.....................................44 


\section{List of Tables}

Table 1 List of Antimony Allyloxide compounds synthesized.......19

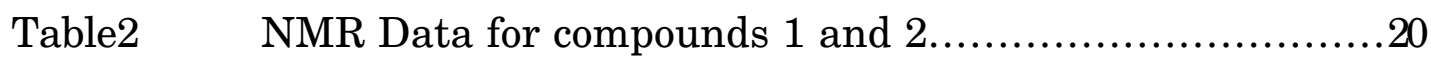

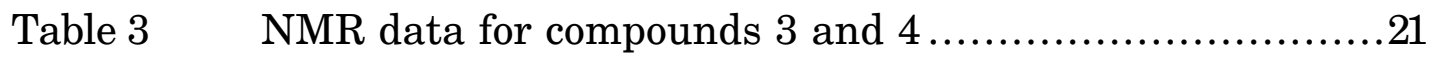

Table 4 NMR data for compounds 5 and Antimony Halides .......22

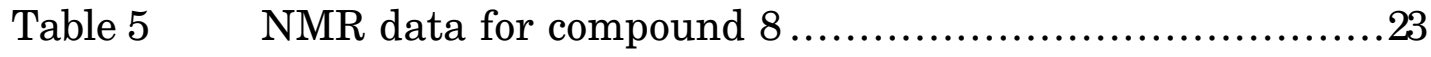

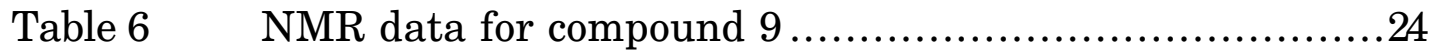




\section{List of Schemes}

Scheme 1 Proposed catalytic oxidation of propene (Grasselli) ........4

Scheme 2 Proposed mechanism of propene ammoxidation ...........5

Scheme 3 Proposed mechanism for the initial stages of

propene oxidation ...........................................

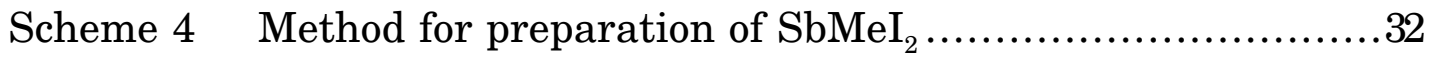

Scheme 5 Proposed Mo coordinations to Sb compounds................40 


\section{List of Figures}

Fiqure 1 Antimony(III) and antimony(V) compound...............1

Fiqure 2 Tris-allyloxide antimony(III), bis-allyloxide antimony(III) methyl and corresponding antimony(V) oxo compounds.2

Fiqure 3 Processes replaced by Sohio process........................... 3

Fiqure 4 Propose intermediates in allylic oxidation .................5

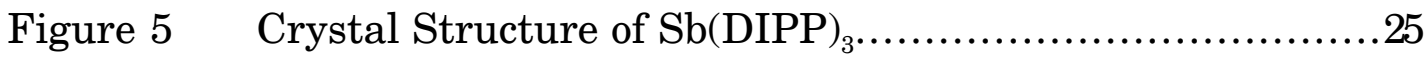

Figure $6 \quad$ Modified Hickman still.......................................29 


\section{Introduction}

Organoantimony compounds are used in a variety of diverse applications. For example, stibines have been used in organic metal vapor phase epitaxy (OMVPE $)^{1}$ and organic metal chemical vapor deposition (OMCVD) ${ }^{2}$ for preparation of semiconducting materials and films. Organoantimony compounds have also been mixed with ceramic powders to prepare commercial composites with higher density and strength. ${ }^{3}$ Other applications include polymerization catalysts, additives for stabilization and flameproofing of plastics and anti-knock fuel additives. ${ }^{4}$

At one time organoantimony compounds, especially organofunctional stibines and stibonic acids, were synthesized in the attempt of finding pharmacologically active substances similar to those of arsenic. ${ }^{4,5}$ The compounds were found to be inferior to their arsenic analogs. With the development of stronger and less toxic antibiotics, the medicinal interest in organoantimony compounds has decreased.

Organoantimony compounds occur where the coordination number of the metal is three $\left(\mathrm{R}_{3} \mathrm{Sb}\right)$, four $\left(\mathrm{R}_{4} \mathrm{Sb}^{+} \mathrm{X}^{-}\right)$, five $\left(\mathrm{R}_{5} \mathrm{Sb}\right)$, and rarely six $\left(\mathrm{LiSbPh}_{6}\right){ }^{5,6}$ The oxidation states of these compounds are usually +3 or +5 . The structures of most antimony(III) compounds is a distorted tetrahedron, with a sterically and chemically active lone pair of electrons occupying one of the tetrahedral positions. The antimony $(\mathrm{V})$ compounds

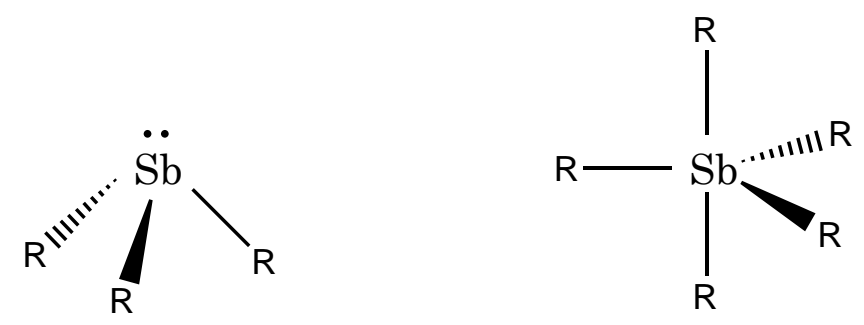

take the shape of a trigonal bipyramid. 
This thesis reports the preparation, characterization and reactivity studies of monomeric $\mathrm{Sb}(\mathrm{III})$ and $\mathrm{Sb}(\mathrm{V})$ compounds. Three specific types of compounds included are tris (allyloxide) compounds, $\mathrm{Sb}(\mathrm{OR})_{3}$; the bis (allyloxide) antimony methyl compounds, $\mathrm{SbMe}(\mathrm{OR})_{2}$; and mono allyloxide antimony bis-methyl compounds, $\mathrm{SbMe}_{2}(\mathrm{OR})$.
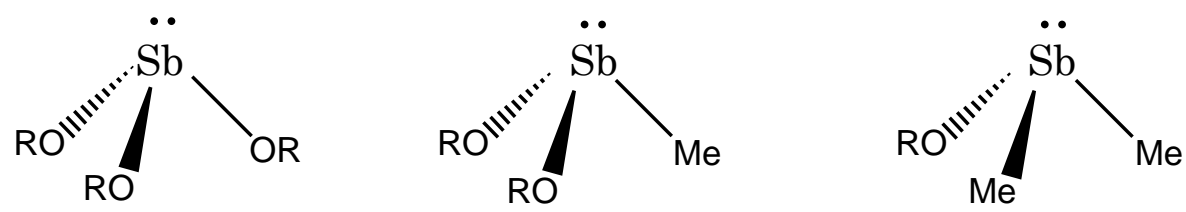

Figure 2. Tris-allyloxide antimony(III), bis-allyloxide antimony(III) methyl, mono-allyloxide antimony(III) bis-methyl

The recognition of the important role of metal oxide supports in heterogeneous catalysis has sparked the study of metal oxides and metal alkoxides. Approximately $25 \%$ of industrial inorganic chemicals are produced by heterogeneous oxidation catalysis. The oxidation catalysts are often composed of a high valent transition metal oxide on a reducible oxide support.

Allylic oxidation, which is the selective oxidation of olefins at the allylic position, is responsible for a large portion of the production of important organic chemicals by heterogeneous oxidation. Also, the study and development of these selective catalysts has led to both successful commercial processes and important concepts dealing with selective oxidation and the phenomena of catalysis in general. ${ }^{9}$

The best known catalytic allylic oxidation is the SOHIO process, developed in 1960. This process uses $\mathrm{MoO}_{3}$ dispersed on a main group oxide. ${ }^{7}$ Oxidation of propene yields acrolein, eq 1. A similar process under ammonia (amoxidation) yields acrylonitrile, eq 2. 


$$
\widehat{\mathrm{C}^{+}}+\mathrm{OH}_{3}+\mathrm{O}_{2} \stackrel{\mathrm{Oi}_{2} \mathrm{O}_{3} / \mathrm{MoO}_{3}}{\longrightarrow} \overbrace{\mathrm{CN}}+\mathrm{H}_{2} \mathrm{O}
$$

The SOHIO ammoxidation accounts for the production of approximately eight billion pounds of acrylonitrile annually. The impact of the SOHIO ammoxidation process was an immediate drastic reduction in acrylonitrile price. Increased production led to the discovery of new applications in resins, rubbers and fibers. ${ }^{8}$ It replaced other processes, which used expensive reagents and oxidants including the acetylene-HCN based system.

$$
\begin{aligned}
& \mathrm{HC} \equiv \mathrm{CH}+\mathrm{HCN} \underset{\mathrm{CuCl}, \mathrm{NH}_{4} \mathrm{Cl}}{\stackrel{80-90^{\circ} \mathrm{C}}{\longrightarrow}} \mathrm{H}_{2} \mathrm{C}=\mathrm{CHCN} \\
& \bigvee_{\mathrm{O}}+\mathrm{HCN} \underset{\text { cat }}{\stackrel{\text { base }}{\longrightarrow}} \mathrm{HOCH}_{2} \mathrm{CH}_{2} \mathrm{CN} \underset{200{ }^{\circ} \mathrm{C}}{\stackrel{-\mathrm{H}_{2} \mathrm{O}}{\longrightarrow}} \mathrm{H}_{2} \mathrm{C}=\mathrm{CHCN}
\end{aligned}
$$

Figure 3. Processes replaced by SOHIO process

The SOHIO processes are heterogeneous processes that use a molybdate catalyst supported on a bismuth or antimony oxide. The most effective catalyst is $\mathrm{MoO}_{3} / \mathrm{Bi}_{2} \mathrm{O}_{3} .{ }^{9}$ Not much is understood concerning the nature of 
this heterogeneous, high pressure and temperature reaction. Grasselli has proposed a catalytic cycle for this reaction. ${ }^{8}$

In Grasselli's proposed cycle (Scheme 1), propylene is activated by the abstraction of a hydrogen $\alpha$ to the double bond to produce an allylic intermediate in the rate-determining step. Oxygen or nitrogen from the lattice can intercept this intermediate. ${ }^{10}$ This is followed by the binding of the allylic moiety to the chemisorption element.

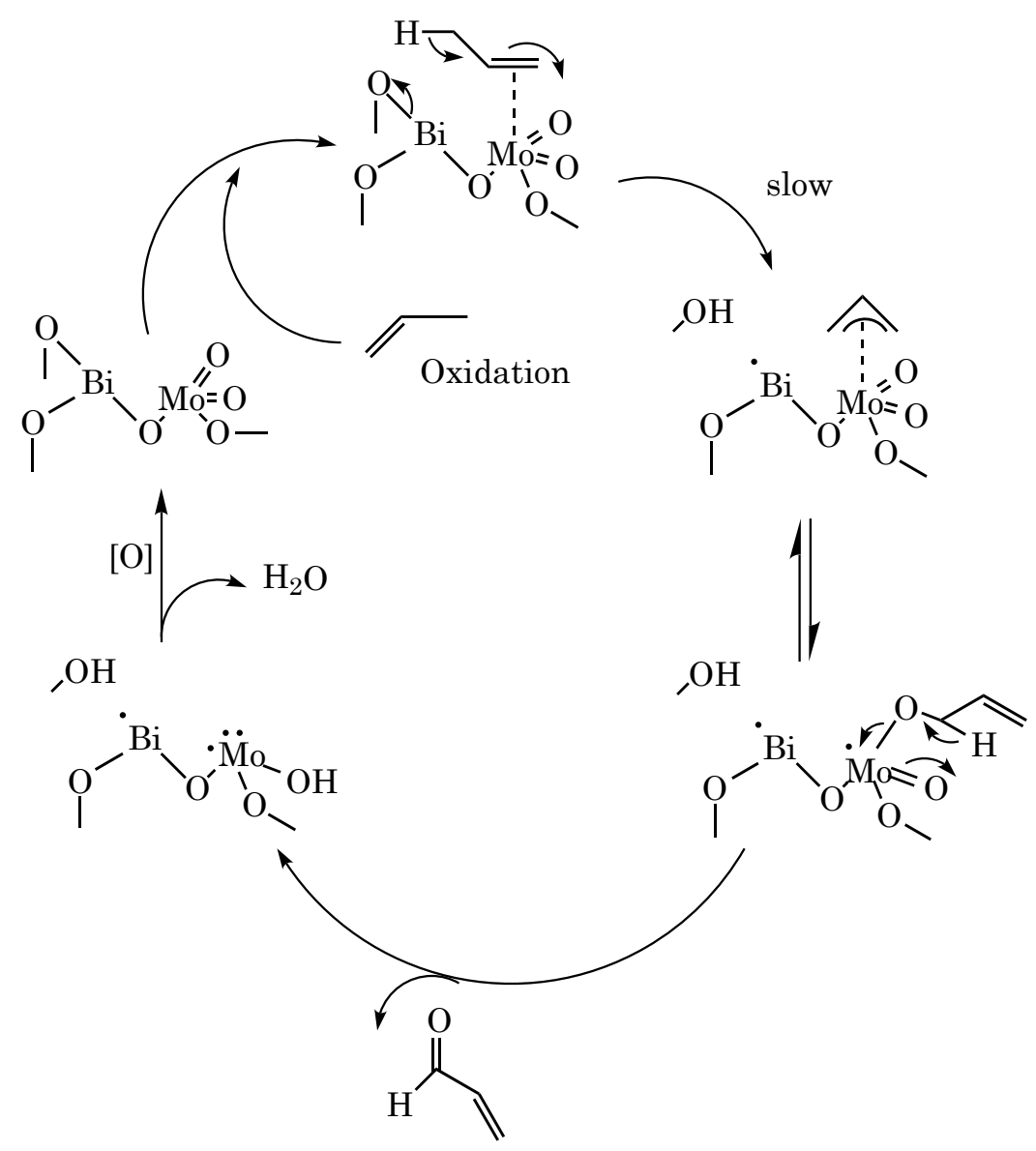

Scheme 1. Proposed catalytic oxidation of propene (Grasselli)

Grasselli and others have used several models to mimic the chemisorption and oxidation elements of this proposed mechanism. Studies 
using ${ }^{13} \mathrm{C}$ and ${ }^{2} \mathrm{H}$ labeling have confirmed that there is indeed an allylic intermediate. ${ }^{11}$ Grasselli also proposes that the allyl chemisorption takes place at the molybdenum moiety. ${ }^{12}$

The oxidation and ammoxidation pathways are very similar. Grasselli has proposed a detailed mechanism (Scheme 2). The initial activation of the propene to an allyl by $\mathrm{H}^{\bullet}$ or $\mathrm{H}^{+}$abstraction is thought to occur on the Mo.

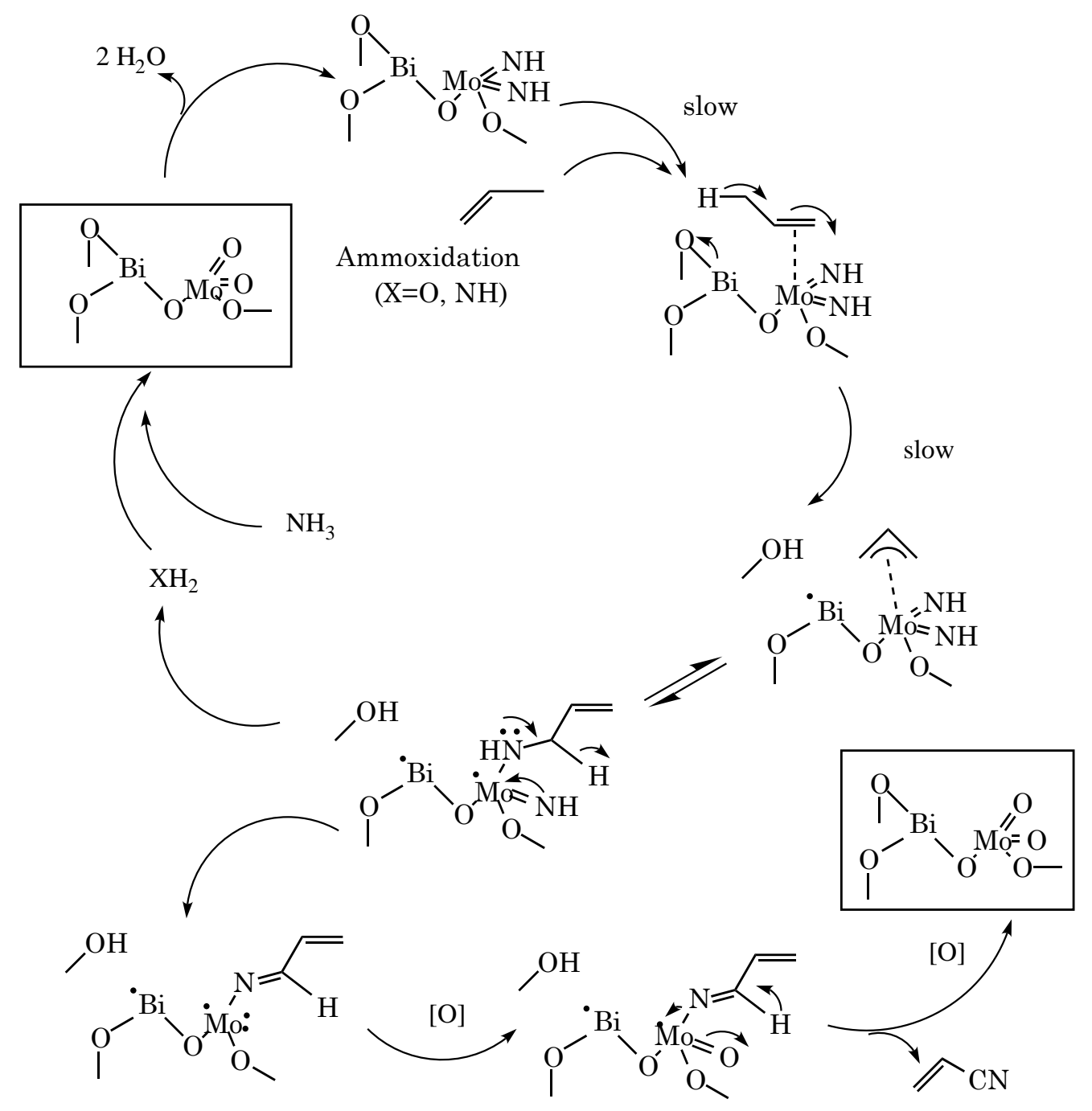

Scheme 2: Proposed mechanism of propene ammoxidation ${ }^{8}$ 
In studies of oxidation and ammoxidation of propene over antimony-tin mixed oxides by Halasz et al, Mossbauer spectroscopy showed the presence of $\mathrm{Sb}(\mathrm{III}), \mathrm{Sb}(\mathrm{V})$, and $\mathrm{Sn}(\mathrm{IV})$ oxides in the active catalyst. ${ }^{14}$ These authors suggest intial activation of the propene by a $\operatorname{Sn}(\mathrm{IV})$ species to give a $\mathrm{Sn} \sigma-$ allyl species. The $\sigma$-allyl is then transferred to the $\mathrm{Sb}(\mathrm{V})$ and oxidized on the antimony (Scheme 3). ${ }^{16}$ Similar alkyl transfers have been observed in homogeneous heterobimetallic complexes. ${ }^{7}$ Antimony has been shown to be an efficient acceptor and donor of allyls. ${ }^{17}$

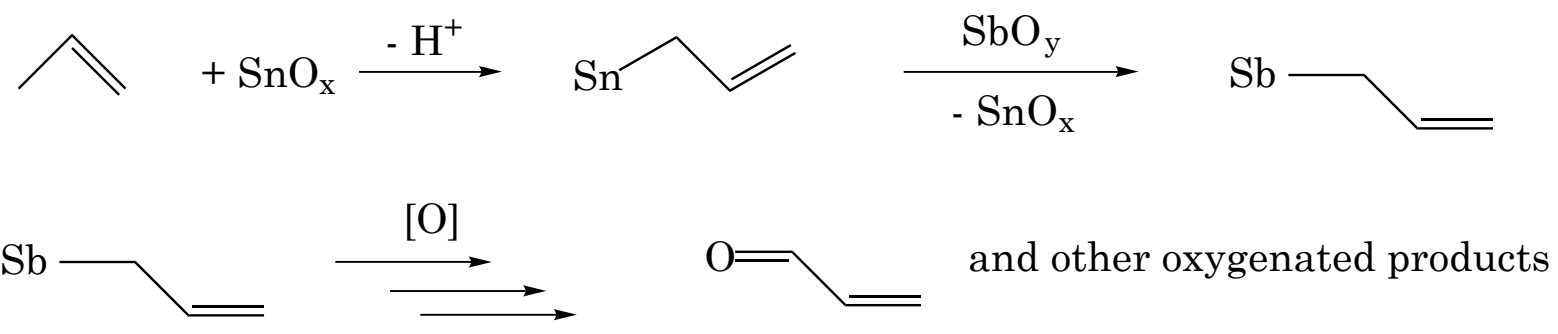

Scheme 3. Proposed mechanism for the initial stages of propene oxidation. ${ }^{17}$

In order to gain insight into the role of the stibia or bismuthia in heterogeneous allylic oxidations, Sb allyloxides were used. Antimony and bismuth are expected to display many of the same reactivity trends being from the same group. Bismuthia is the more commonly used industrial support; however, the toxicity of bismuth and its compounds is troublesome. Antimony compounds would therefore be more environmentally suitable. Rothwell and co-workers ${ }^{14}$ have shown that alkoxides of early transition metals can mimic the structure and chemical reactivity of the silica, titania, vanadia and other electrophilic metal oxides. We propose that antimony allyloxides will similarly provide models for the more electron-rich bismuthia. 
Little work has been done on modeling antimony organometallics with oxide or alkoxide ligands. This is perhaps due to the facile loss of the ligands in proton rich environments. Wieber and co-workers ${ }^{15}$ have oxidized $\mathrm{Sb}(\mathrm{III})$ alkoxides using thionyl chloride or bromine to prepare the stibonic esters, eq 2 . However, dimeric $\mathrm{Sb}(\mathrm{V})$ alkoxy bridged compounds with coordinating halides were formed.

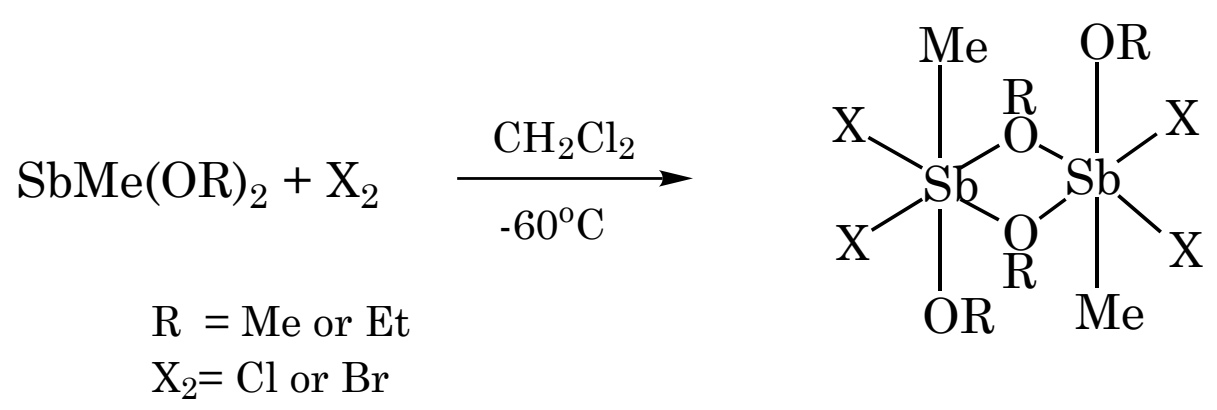

Using monomeric $\mathrm{Sb}(\mathrm{III})$ allyloxides, insight may be gained into the role of the antimony and bismuth in allylic oxidations. The antimony (V) oxo compounds may also model potential intermediates in the heterogeneous catalytic oxidation (Figure 4).
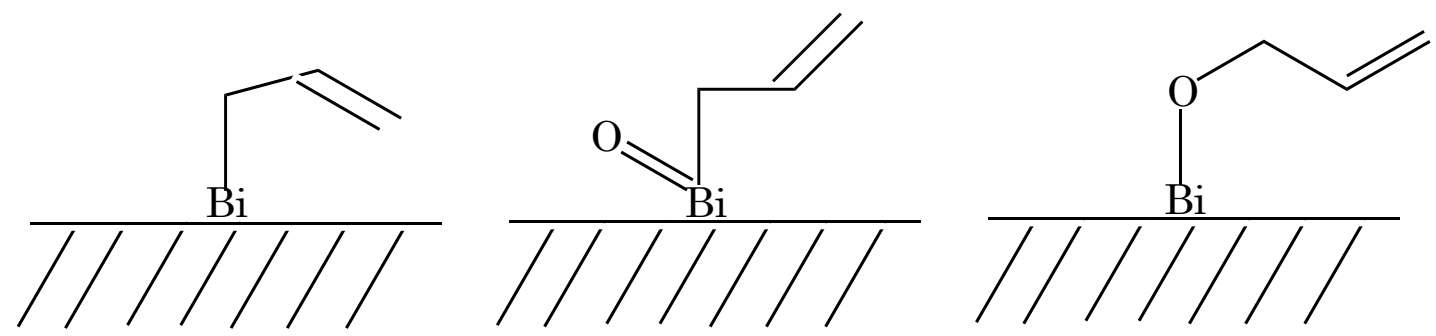

Figure 4. Proposed intermediates in allylic oxidation.

Antimony allyls, oxo-allyls and allyloxides are all potential species in the initial stages of propene oxidation. The synthesis and characterization 
of these model compounds was undertaken. Also of interest are the oxidation and intermetallic transfer reactions.

The project's goals are to prepare and characterize the tris, bis, and mono(allyloxide) antimony methyl compounds, oxidize these compounds, in order to produce a reactive $\mathrm{Sb}(\mathrm{V})$ oxo species, and to study the bimetallic reactivity of antimony allyloxides with molybdenum complexes. 


\section{Experimental}

\section{$\underline{\text { Reagents }}$}

Reagent grade solvents were purified by standard methods and freshly distilled under a nitrogen atmosphere. Diethyl ether, hexane, tetrahydrofuran and toluene were refluxed over sodium benzophenone ketyl. A small quantity of tetraglyme (tetraethylene glycol dimethyl ether) was added to the hexane to solubilize the ketyl that is formed. The solvents were then stored in vacuum flasks containing the sodium benzophenone ketyl and were vacuum distilled prior to use. Chlorinated solvents, $\mathrm{CHCl}_{3}$ and $\mathrm{CH}_{2} \mathrm{Cl}_{2}$, were distilled over $\mathrm{P}_{2} \mathrm{O}_{5}$. The deuterated solvents, $\mathrm{CHCl}_{3}-\mathrm{d}_{1}$ (Aldrich, 99.6\%), $\mathrm{C}_{6} \mathrm{H}_{6}-\mathrm{d}_{6}$ (Cambridge Isotope Laboratories, 99.6\%), and tetrahydrofuran- $\mathrm{d}_{8}$ (Cambridge Isotope Laboratories, 99.5\%) were dried over activated $4 \AA$ molecular sieves and distilled prior to use.

Antimony trichloride (Aldrich) was sublimed to a $\mathrm{CO}_{2}$ /acetone cooled probe prior to use. MeI (Aldrich), MeMgI (Adrich, 3.0 M in diethyl ether), $\mathrm{SbPh}_{3}$ (Aldrich), red $\mathrm{HgO}$ (Aldrich), iodine (Aldrich), iodobenzene diacetate (Aldrich), sodium hydroxide (Aldrich), potassium permanganate (Aldrich), $\mathrm{Ag}_{2} \mathrm{O}$ (Aldrich), $\mathrm{OsO}_{4}$ (Aldrich), acetyl chloride (Aldrich), Oxone ${ }^{\circledR}\left(2 \mathrm{KHSO}_{5} \cdot \mathrm{KHSO}_{4} \cdot \mathrm{K}_{2} \mathrm{SO}_{4}\right.$,Aldrich), trifluoracetone (Aldrich), acetone HPLC (Aldrich), trimethylsilyl chloride (Aldrich), trimethylaminetrioxide (Aldrich), diisopropoylphenol (Aldrich), 3-methyl3-buten-1-ol (Aldrich), 2-methyl-3-buten-2-ol (Aldrich), 3-methyl-2-buten-1-ol (Aldrich), 3-chloroperoxbenzoic acid (Aldrich), allyl alcohol (Aldrich), and triethyl amine (Aldrich) were used without further purification. Iodosobenzene ${ }^{18}, \mathrm{PhCH}_{2} \mathrm{Mn}(\mathrm{CO})_{5}, \mathrm{MoO}\left(\mathrm{S}_{2} \mathrm{CNEt}_{2}\right)_{2}, \mathrm{MoCl}_{4}\left(\mathrm{CH}_{3} \mathrm{CN}\right)_{2}$, and $\mathrm{MoCl}_{4}(\mathrm{THF})_{2}$ were all prepared using literature procedures. 


\section{Instrumentation}

${ }^{1} \mathrm{H}$ and ${ }^{13} \mathrm{C}$ NMR spectra were collected using JEOL GX-270 and JEOL Eclipse 270 FT-NMR spectrometers operating in the FT mode at $270 \mathrm{MHz}$ $\left({ }^{1} \mathrm{H}\right)$ or $67.9 \mathrm{MHz}\left({ }^{13} \mathrm{C}\right)$. The ${ }^{1} \mathrm{H}$ chemical shifts are referenced to the residual proton peaks of benzene- $\mathrm{d}_{6}$ at $\delta 7.15 \mathrm{ppm}$ ( vs. TMS), chloroform- $\mathrm{d}_{1}$ at $\delta 7.24$ ppm (vs. TMS). The ${ }^{13} \mathrm{C}$ resonances are referenced to the residual central peak of benzene- $\mathrm{d}_{6}$ at $\delta 128.0 \mathrm{ppm}$ ( vs. TMS) or chloroform- $\mathrm{d}_{1}$ at $\delta 77.0 \mathrm{ppm}$ (vs. TMS). The corresponding ${ }^{1} \mathrm{H}$ and ${ }^{13} \mathrm{C}\left\{{ }^{1} \mathrm{H}\right\}$ NMR spectral data for Compounds 1-10 are listed in Tables 2-6.

\section{General Procedures}

Due to the air- and moisture-sensitivity of the compounds in this study, all reactions and manipulations were carried out in a glove box or on a double manifold high vacuum line. The compounds were synthesized using standard Schlenk techniques or pressure-equalizing swivel filter-frits equipped with Teflon stopcocks. The addition of stoichiometric amounts of volatile reagents was accomplished with the use of a calibrated gas bulb fitted with Teflon stopcocks. NMR tubes were sealed with a torch under a vacuum. Infrared spectra of compounds were taken using a solution cell.

\section{Synthesis of Compounds}

Preparation of sodium salts

Sodium hydride was placed in a frit and washed with hexane. The sodium hydride was then weighed (1 eq.) into a $100 \mathrm{~mL}$ two-necked round bottom flask. The flask was then attached to a filter-frit assembly and evacuated. Ether $(\sim 50 \mathrm{~mL})$ was added via vacuum distillation into the reaction flask. The reaction flask was submerged in a dry ice/acetone slush bath. Under an Ar flush, the parent alcohol (1.1 eq.) was introduced via 
syringe through the side arm. The solution was warmed to room temperature and stirred until all of the sodium hydride was consumed and hydrogen evolution ceased. The ether was removed and the product was washed with hexane $(\sim 40 \mathrm{~mL})$ to yield the white sodium salts in $80-95 \%$ yields.

Preparation of $\mathrm{SbMe}_{3} \mathrm{I}_{2}$

A dry three-neck, 3 liter flask was fitted with a reflux condenser, an addition funnel, stir bar, and a stopper. The flask was purged with nitrogen for 20 minutes and maintained with a positive pressure of nitrogen for the rest of the preparation. Methyl magnesium iodide ( 3.0 M in diethyl ether, $200 \mathrm{~mL}, 600 \mathrm{mmol}$ ) was introduced into the flask which was cooled to $-20^{\circ} \mathrm{C}$ and maintained by addition of dry ice to an acetone bath. A solution of antimony trichloride ( $45.633 \mathrm{~g}, 200 \mathrm{mmol}$ ) in $\sim 100 \mathrm{~mL}$ of dry diethyl ether was cannulated into the addition funnel and then added dropwise $(\sim 7$ $\mathrm{mL} / \mathrm{min}$ ) to the Grignard solution. The Grignard solution turned yellow and then grayish on further addition of antimony trichloride. At the end of the reaction there were two phases, a yellow upper layer and a black lower layer. The stirrer was stopped and the solution was cooled well below $-20{ }^{\circ} \mathrm{C}$. The addition funnel was replaced with a stopper, and the reflux condenser was replaced with a distillation head. The receiving flask was fitted with reflux condenser and a stir bar. The dry ice/acetone bath was removed and replaced with a heating mantle. The receiving flask was cooled with ice piled around the neck. Diethyl ether and trimethyl stibine were distilled until the stillhead temperature reached $78^{\circ} \mathrm{C}$. Fumes were observed in the reaction flask near the end of the distillation. When the distillation was completed the distillation head was replaced with a stopper, and the flask containing the $\mathrm{SbMe}_{3}$ and the ether was kept cold by using an ice bath. 
Under a positive pressure of $\mathrm{N}_{2}$, the flask containing the ethereal solution of trimethyl stibine was fitted with an addition funnel. The addition funnel was charged with $350 \mathrm{~mL}$ of an ethereal solution of $\mathrm{I}_{2}(50.76 \mathrm{~g}, 200$ mmol), based on a reaction with $200 \mathrm{mmol}$ of $\mathrm{SbCl}_{3}$. The iodine was added dropwise to the cold distillate with stirring until the color of iodine persisted. The $\mathrm{SbMe}_{3} \mathrm{I}_{2}$ solid was collected on a Buchner funnel, washed with water and recrystallized from with ethanol. (35.391, $42 \%$ yield.)

\section{Preparation of $\mathrm{SbMe}_{2} \mathrm{I}$}

Antimony trimethyl diiodide $(1.00 \mathrm{~g}, 2.38 \mathrm{mmol})$ was weighed into a 25 $\mathrm{mL}$ round bottom flask, which was fitted with a reflux condenser. Approximately $15 \mathrm{~mL}$ of toluene was vacuum distilled into the reaction flask. The solution was refluxed overnight under an argon atmosphere. The MeI that was produced in the reaction was removed in vacuo, along with the toluene, to afford $0.602 \mathrm{~g}$ of $\mathrm{SbMe}_{2} \mathrm{I}$, in $91 \%$ yield. The product was a gummy yellow solid.

Preparation of $\mathrm{SbMeI}_{2}$

$\mathrm{SbMe}_{3} \mathrm{I}_{2}(10.0 \mathrm{~g}, 23.7 \mathrm{mmol})$ was introduced into a $250 \mathrm{~mL}$ round bottom flask along with $\sim 120 \mathrm{~mL}$ of toluene, which was fitted with a reflux condenser. The solution was refluxed overnight under an argon atmosphere. The methyl iodide produced in the reaction was removed by vacuum distillation. The reflux condenser was replaced with a rubber septum. The solution containing the $\mathrm{SbMe}_{2} \mathrm{I}$ was titrated, via cannulation, with a toluene solution $(\sim 350 \mathrm{~mL})$ of iodine $(6.019 \mathrm{~g})$ until the color of iodine persisted. The rubber septum was removed and replaced with a filter-frit assembly. The solution was filtered and the toluene was removed to afford yellow crystalline needles of $\mathrm{SbMeI}_{2}(5.032 \mathrm{~g}, 54 \%$ yield $)$. 


\section{Preparation of $\mathrm{Sb}\left(\mathrm{OCMe}_{2} \mathrm{CH}=\mathrm{CH}_{2}\right)_{3} \mathbf{1}$}

Antimony trichloride ( $4.00 \mathrm{~g}, 17.6 \mathrm{mmol}$ ) was weighed into a $50 \mathrm{~mL}$ twonecked round bottom flask. The flask was attached to a filter-frit assembly, cooled via dry ice/acetone bath and evacuated. Approximately $30 \mathrm{~mL}$ of ether was vacuum distilled into the reaction flask. The solution was held under an argon atmosphere and 2-methyl-3-buten-2-ol (5.499 mL, 52.8 mmol) was added via syringe. After complete addition of 2-methyl-3-buten2-ol, an excess of triethylamine $(11.0 \mathrm{~mL}, 80.6 \mathrm{mmol})$ was added, also via syringe. Triethylamine hydrochloride immediately precipitated from solution. The reaction solution was stirred for 1.5 hours. Ether was removed in vacuo and replaced with hexane $(\sim 25 \mathrm{~mL})$. The hexane solution was filtered to remove the hydrochloride salt. The salt was washed several times with hexane. The hexane was removed in vacuo to afford 5.02 $\mathrm{g}$ of $\mathrm{Sb}\left(\mathrm{OCMe}_{2} \mathrm{CH}=\mathrm{CH}_{2}\right)_{3} 1$, a yellow oily liquid, in $76 \%$ yield. Anal. Calcd for $\mathrm{Sb}\left(\mathrm{OCMe}_{2} \mathrm{CH}=\mathrm{CH}_{2}\right)_{3}: \mathrm{C}, 47.70 ; \mathrm{H}, 7.23$. Found: C, 47.54; H, 7.03.

Preparation of $\mathrm{Sb}\left(\mathrm{OCH}_{2} \mathrm{CH}=\mathrm{CH}_{2}\right)_{3} 2$

Antimony trichloride ( $0.360 \mathrm{~g}, 1.58 \mathrm{mmol}$ ) was weighed into a $25 \mathrm{~mL}$ two-necked round bottom flask, which was attached to a filter-frit assembly, cooled via dry ice/acetone bath and evacuated. Approximately $10 \mathrm{~mL}$ of ether was vacuum distilled into the reaction flask. The solution was held under an argon atmosphere and allyl alcohol $(0.320 \mathrm{~mL}, 4.74 \mathrm{mmol})$ was added via syringe. After complete addition of the allyl alcohol, an excess of triethylamine $(1.0 \mathrm{~mL}, 7.33 \mathrm{mmol})$ was added, also via syringe. Triethylamine hydrochloride immediately precipitated from the solution. The reaction solution was stirred for 3.5 hours. Ether was removed in vacuo and replaced with hexane $(\sim 15 \mathrm{~mL})$. The hexane solution was filtered to 
remove the hydrochloride salt. The salt was washed several times with hexane. The hexane was removed in vacuo to afford $0.270 \mathrm{~g}$ of $\mathrm{Sb}\left(\mathrm{OCH}_{2} \mathrm{CH}=\mathrm{CH}_{2}\right)_{3}, 2$, a yellow oily liquid, in $58 \%$ yield. Preparation of $\mathrm{Sb}\left(\mathrm{OCH}_{2} \mathrm{CH}=\mathrm{CMe}_{2}\right)_{3} 3$

Antimony trichloride ( $4.00 \mathrm{~g}, 17.5 \mathrm{mmol}$ ) was weighed into a $50 \mathrm{~mL}$ twonecked round bottom flask, which was attached to a filter-frit assembly, cooled via dry ice/acetone bath and evacuated. Approximately $30 \mathrm{~mL}$ of ether was vacuum distilled into the reaction flask. The solution was held under an argon atmosphere and 3-methyl-2-buten-1-ol (5.34 mL, $52.5 \mathrm{mmol})$ was added via syringe. After complete addition of the 3-methyl-2-buten-1-ol, an excess of triethylamine $(11.0 \mathrm{~mL}, 80.6 \mathrm{mmol})$ was added, also via syringe. Triethylamine hydrochloride immediately precipitated from solution. The reaction solution was stirred for 1.5 hours. Ether was removed in vacuo and replaced with hexane $(\sim 25 \mathrm{~mL})$. The hexane solution was filtered to remove the hydrochloride salt. The salt was washed several times with hexane, which was removed in vacuo to afford $5.263 \mathrm{~g}$ of $\mathrm{Sb}\left(\mathrm{OCH}_{2} \mathrm{CH}=\mathrm{CMe}_{2}\right)_{3}$ 3, a yellow-brownish oily liquid, in $80 \%$ yield. Upon vacuum distillation at $130^{\circ} \mathrm{C}$, the purified oil was light yellow in color. Anal. Calcd for $\mathrm{Sb}\left(\mathrm{OCMe}_{2} \mathrm{CH}=\mathrm{CH}_{2}\right)_{3}: \mathrm{C}, 47.70 ; \mathrm{H}$, 7.23. Found: $\mathrm{C}, 47.38 ; \mathrm{H}$, 7.18.

\section{Preparation of $\mathrm{Sb}\left(\mathrm{OCH}_{2} \mathrm{CH}_{2}\left(\mathrm{CH}_{3}\right) \mathrm{C}=\mathrm{CH}_{2}\right)_{3} 4$}

Antimony trichloride ( $4.00 \mathrm{~g}, 17.5 \mathrm{mmol}$ ) was weighed into a $50 \mathrm{~mL}$ twonecked round bottom flask, which was attached to a filter-frit assembly, cooled via dry ice/acetone bath and evacuated. Approximately $30 \mathrm{~mL}$ of ether was vacuum distilled into the reaction flask. The solution was held under an argon atmosphere and 3-methyl-3-buten-1-ol (5.312 mL, 52.5 mmol) was added via syringe. After complete addition of the 3-methyl-3- 
buten-1-ol, an excess of triethylamine $(11.0 \mathrm{~mL}, 80.6 \mathrm{mmol})$ was added, also via syringe. Triethylamine hydrochloride immediately precipitated from solution. The reaction solution was stirred for 1.5 hours. Ether was removed in vacuo and replaced with hexane $(\sim 25 \mathrm{~mL})$. The hexane solution was filtered to remove the hydrochloride salt. The salt was washed several times with hexane. The hexane was removed in vacuo to afford 2.90 $\mathrm{g}$ of $\mathrm{Sb}\left(\mathrm{OCH}_{2} \mathrm{CH}_{2}\left(\mathrm{CH}_{3}\right) \mathrm{C}=\mathrm{CH}_{2}\right)_{3} 4$, an orangish-brown oily liquid, in $44 \%$ yield. Upon vacuum distillation at $110^{\circ} \mathrm{C}$, the purified oil was light yellow in color. Anal. Calcd for $\mathrm{Sb}\left(\mathrm{OCMe}_{2} \mathrm{CH}=\mathrm{CH}_{2}\right)_{3}: \mathrm{C}, 47.70 ; \mathrm{H}, 7.23$. Found: C, 47.35; H, 7.05 .

Attempted preparation of $\mathrm{Sb}\left(\mathrm{OCMe}_{2} \mathrm{CH}_{2}=\mathrm{CH}_{2}\right)_{2} \mathrm{Cl}$

$\mathrm{Sb}\left(\mathrm{OCMe}_{2} \mathrm{CH}=\mathrm{CH}_{2}\right)_{3} \mathbf{1}(0.0064 \mathrm{~g}, .017 \mathrm{mmol})$ was added to a $10 \mathrm{~mL}$ round bottomed flask with an attached calibrated $(21.05 \mathrm{~mL})$ gas bulb. Benzene was vacuum distilled in. Using the gas bulb acetyl chloride ( $0.133 \mathrm{~g}, 149$ torr $0.169 \mathrm{mmol}$ ) was transferred into the reaction flask, and the reaction was stirred overnight. The benzene was removed in vacuo to give a viscous dark brown oil. No yield was taken. Spectral data indicated that $\mathrm{Sb}\left(\mathrm{OCMe}_{2} \mathrm{CH}=\mathrm{CH}_{2}\right)_{2} \mathrm{Cl}$ is present along with $\mathrm{CH}_{3} \mathrm{COOCH}_{2} \mathrm{CH}=\mathrm{CH}_{2}$. Preparation of $\mathrm{CH}_{3} \mathrm{COOCH}_{2} \mathrm{CH}=\mathrm{CH}_{2}$

Approximately $25 \mathrm{~mL}$ of hexane was added by vacuum distillation into a $50 \mathrm{~mL}$ two-necked flask, attached to a filter-frit assembly,. Acetyl chloride ( $0.5 \mathrm{~mL}, 0.552 \mathrm{~g}, 7.04 \mathrm{mmol})$ was added via syringe, followed by syringe addition of 2-methyl-3-buten-2-ol ( $0.753 \mathrm{~mL}, 0.605 \mathrm{~g}, 7.04 \mathrm{mmol}$ ). The solution was stirred for $\sim 15$ minutes; then an excess of triethylamine (1.0 $\mathrm{mL}, 7.33 \mathrm{mmol}$ ) was added via syringe. Triethylamine hydrochloride immediately precipitated. The solution was filtered and the hexanes and excess triethylamine removed in vacuo. $\mathrm{NMR}$ data: ${ }^{1} \mathrm{H} \mathrm{NMR}(270 \mathrm{MHz})$ 
$\left(\mathrm{C}_{6} \mathrm{D}_{6}\right): \delta 6.07-6.04\left(\mathrm{~m}, 1 \mathrm{H}, \mathrm{sp}^{2}\right.$ proton), 5.07 and $4.89(\mathrm{dd}, 1 \mathrm{H}$, vinyl protons), $1.41\left(\mathrm{~s}, 6 \mathrm{H}, \mathrm{CH}_{3}\right), 1.14\left(\mathrm{~s}, 3 \mathrm{H}, \mathrm{CH}_{3}\right)$. No yield was taken.

Preparation of $\mathrm{SbMe}\left(\mathrm{OCMe}_{2} \mathrm{CH}=\mathrm{CH}_{2}\right)_{2} \mathbf{5}$

$\mathrm{SbMeI}_{2}(1.00 \mathrm{~g}, 2.56 \mathrm{mmol})$ and $\mathrm{NaOCMe}_{2} \mathrm{CH}_{2}=\mathrm{CH}_{2}(0.553 \mathrm{~g}, 5.12 \mathrm{mmol})$ were weighed into a $100 \mathrm{~mL}$ flask with an attached filter-frit assembly. The assembly was then evacuated. THF $(\sim 50 \mathrm{~mL})$ was introduced to the flask via vacuum distillation, and the solution was warmed to room temperature and stirred overnight under a positive argon atmosphere. THF was removed and replaced with hexane $(\sim 35 \mathrm{~mL})$. The hexane solution was filtered to remove NaI. Concentration of the hexane yielded $0.3015 \mathrm{~g}$ of $\mathrm{SbMe}\left(\mathrm{OCMe}_{2} \mathrm{CH}=\mathrm{CH}_{2}\right)_{2} \mathbf{5}$, a clear, bright, yellow oil in $38.6 \%$ yield. Anal. Calcd for $\mathrm{SbMe}\left(\mathrm{OCMe}_{2} \mathrm{CH}=\mathrm{CH}_{2}\right)_{2}$ : C, 43.0; H, 6.91. Found: C, 42.78; H, 7.21. Preparation of $\mathrm{SbMe}\left(\mathrm{OCH}_{2} \mathrm{CH}=\mathrm{CMe}_{2}\right)_{2} 6$

$\mathrm{SbMeI}_{2}(0.384 \mathrm{~g}, 0.984 \mathrm{mmol})$ and $\mathrm{NaOCH}_{2} \mathrm{CH}=\mathrm{CMe}_{2}(0.213 \mathrm{~g}, 1.97 \mathrm{mmol})$ were weighed into a $25 \mathrm{~mL}$ flask with an attached filter-frit assembly. The assembly was then evacuated. THF $(\sim 15 \mathrm{~mL})$ was introduced to the flask via vacuum distillation and the solution was warmed to room temperature and stirred overnight under a positive argon atmosphere. THF was removed and replaced with hexane $(\sim 15 \mathrm{~mL})$. The hexane solution was filtered to remove NaI. Concentration of the hexane yielded $0.1002 \mathrm{~g}$ of $\mathrm{SbMe}\left(\mathrm{OCH}_{2} \mathrm{CH}=\mathrm{CMe}_{2}\right)_{2}$ 6, a dark brown oil in $33.4 \%$ yield. NMR data indicates that is this product was formed, but due to impurities, clean spectra were not obtained.

Preparation of $\mathrm{SbMe}\left(\mathrm{OCH}_{2} \mathrm{CH}_{2}\left(\mathrm{CH}_{3}\right) \mathrm{C}=\mathrm{CH}_{2}\right)_{2} \mathrm{7}$

$\mathrm{SbMeI}_{2}(0.384 \mathrm{~g}, 0.984 \mathrm{mmol})$ and $\mathrm{NaOCH}_{2} \mathrm{CH}_{2}\left(\mathrm{CH}_{3}\right) \mathrm{C}=\mathrm{CH}_{2}(0.213 \mathrm{~g}, 1.97$ mmol) were weighed into a $25 \mathrm{~mL}$ flask with an attached filter-frit 
assembly. The assembly was then evacuated. THF $(\sim 15 \mathrm{~mL})$ was introduced to the flask via vacuum distillation and the solution was warmed to room temperature and stirred overnight under a positive argon atmosphere. THF was removed and replaced with hexane ( 15 mL). The hexane solution was filtered to remove NaI. Concentration of the hexane yielded $0.0807 \mathrm{~g}$ of $\mathrm{SbMe}\left(\mathrm{OCH}_{2} \mathrm{CH}_{2}\left(\mathrm{CH}_{3}\right) \mathrm{C}=\mathrm{CH}_{2}\right)_{2}$, a dark yellow-brown oil in $26.9 \%$ yield. NMR data indicates that the desired product was formed, but due to impurities, clean spectra were not obtained. Preparation of $\mathrm{SbMe}_{2}\left(\mathrm{OCMe}_{2} \mathrm{CH}=\mathrm{CH}_{2}\right) \mathbf{8}$

$\mathrm{SbMe}_{2} \mathrm{I}(0.200 \mathrm{~g}, 0.718 \mathrm{mmol})$ and $\mathrm{NaOCMe}_{2} \mathrm{CH}=\mathrm{CH}_{2}(0.078 \mathrm{~g}, 0.718 \mathrm{mmol})$ were weighed into a $25 \mathrm{~mL}$ flask with an attached filter-frit assembly. The assembly was then evacuated. THF $(\sim 15 \mathrm{~mL})$ was introduced to the flask via vacuum distillation and the solution was warmed to room temperature and stirred overnight under a positive argon atmosphere. THF was removed and replaced with hexane $(\sim 15 \mathrm{~mL})$. The hexane solution was filtered to remove NaI. Concentration of the hexane yielded $0.0901 \mathrm{~g}$ of $\mathrm{SbMe}_{2}\left(\mathrm{OCMe}_{2} \mathrm{CH}=\mathrm{CH}_{2}\right), \mathbf{8}$, a dark brown oil in $53 \%$ yield.

Preparation of $\mathrm{SbMe}_{2}(\mathrm{DIPP}) \mathbf{9}$

$\mathrm{SbMe}_{2} \mathrm{I}(0.100 \mathrm{~g}, 0.359 \mathrm{mmol})$ and $\mathrm{Na}$ (diisopropylphenol) (0.072 g, 0.359 $\mathrm{mmol}$ ) were weighed into a $25 \mathrm{~mL}$ flask which was attached to a filter-frit assembly. The assembly was then evacuated. THF $(\sim 15 \mathrm{~mL})$ was introduced to the flask via vacuum distillation. The solution was warmed to room temperature and stirred overnight under a positive argon atmosphere. THF was removed and replaced with hexane $(\sim 15 \mathrm{~mL})$. The hexane solution was filtered to remove NaI. Concentration of the hexane yielded $0.0913 \mathrm{~g}$ of $\mathrm{SbMe}_{2}$ (DIPP) 9, a white solid in $77 \%$ yield. Anal. Calcd for $\mathrm{SbMe}_{2}(\mathrm{DIPP})$ : C, 51.40; H, 6.48. Found C, 51.38, H, 6.53. 
Preparation of $\mathrm{SbMe}_{3}\left(\mathrm{OCMe}_{2} \mathrm{CH}_{2}=\mathrm{CH}_{2}\right)_{2} \mathbf{1 0}$

$\mathrm{SbMe}_{3} \mathrm{I}_{2}(1.00 \mathrm{~g}, 2.38 \mathrm{mmol})$ and $\mathrm{Na}\left(\mathrm{OCMe}_{2} \mathrm{CH}=\mathrm{CH}_{2}\right)(0.514 \mathrm{~g}, 4.75 \mathrm{mmol})$ were weighed into a $100 \mathrm{~mL}$ flask which was attached to a filter-frit assembly. The assembly was then evacuated. THF $(\sim 35 \mathrm{~mL})$ was introduced to the flask via vacuum distillation. The solution was warmed to room temperature and stirred overnight under a positive argon atmosphere. THF was removed and replaced with hexane $(\sim 35 \mathrm{~mL})$. The hexane solution was filtered to remove NaI. Concentration of the hexane yielded $0.4700 \mathrm{~g}$ of $\mathrm{SbMe}_{3}\left(\mathrm{OCMe}_{2} \mathrm{CH}=\mathrm{CH}_{2}\right)_{2} \mathbf{1 0}$, a white gummy solid in $58.7 \%$ yield. ${ }^{1} \mathrm{H}$ and ${ }^{13} \mathrm{C}\left\{{ }^{1} \mathrm{H}\right\}$ NMR data indicated the presence of isomers. Anal. Calcd for $\mathrm{SbMe}_{3}\left(\mathrm{OCMe}_{2} \mathrm{CH}=\mathrm{CH}_{2}\right)_{2}$ : C, 46.32; H, 8.09. Found: C,45.96; $\mathrm{H}, 8.23$. 
Table 1 List of Antimony Allyloxide compounds synthesized.

\author{
$\mathrm{Sb}\left(\mathrm{OCMe}_{2} \mathrm{CH}=\mathrm{CH}_{2}\right)_{3} \mathbf{1}$ \\ $\mathrm{Sb}\left(\mathrm{OCH}_{2} \mathrm{CH}=\mathrm{CH}_{2}\right)_{3} 2$ \\ $\mathrm{Sb}\left(\mathrm{OCH}_{2} \mathrm{CH}=\mathrm{CMe}_{2}\right)_{3} \mathbf{3}$ \\ $\mathrm{Sb}\left(\mathrm{OCH}_{2} \mathrm{CH}_{2}\left(\mathrm{CH}_{3}\right) \mathrm{C}=\mathrm{CH}_{2}\right)_{3} 4$ \\ $\mathrm{SbMe}\left(\mathrm{OCMe}_{2} \mathrm{CH}=\mathrm{CH}_{2}\right)_{2} \mathbf{5}$ \\ $\operatorname{SbMe}\left(\mathrm{OCH}_{2} \mathrm{CH}=\mathrm{CMe}_{2}\right)_{2} 6$ \\ $\mathrm{SbMe}\left(\mathrm{OCH}_{2} \mathrm{CH}_{2}\left(\mathrm{CH}_{3}\right) \mathrm{C}=\mathrm{CH}_{2}\right)_{2} \mathbf{7}$ \\ $\mathrm{SbMe}_{2}\left(\mathrm{OCMe}_{2} \mathrm{CH}=\mathrm{CH}_{2}\right) 8$ \\ $\mathrm{SbMe}_{2}(\mathrm{DIPP}) \mathbf{9}$ \\ $\mathrm{SbMe}_{3}\left(\mathrm{OCMe}_{2} \mathrm{CH}=\mathrm{CH}_{2}\right)_{2} \mathbf{1 0}$
}

